\title{
Analysis of Employee Satisfaction Towards Salary, Position, Position Promotion, And Supervision
}

\author{
Evan Mardua Putra ${ }^{1}$, Lise Asnur ${ }^{2 *}$ \\ 1,2Program Studi D4 Manajemen Perhotelan, Universitas Negeri Padang, Padang, Indonesia
}

\section{A R T I C L E I N F O}

Article history:

Received 20 May 2020

Received in revised form 15 June 2020

Accepted 18 August 2020

Available online 01

November 2020

Keywords:

Employee Job Satisfaction

\section{A B S T R A C T}

Job satisfaction is a general attitude towards one's job, as the difference between the amount of reward received by workers and the amount of reward that is believed to be received. This research aims to analyze employee job satisfaction with salary, position, promotion, and supervision. This research is a quantitative study using a survey method. The population in this study were 70 people. The sample was obtained using a saturated sample technique. The data in this study were collected using a questionnaire and documentation. Data were analyzed using the principles of editing, tabulating, analyzing, interpreting, and concluding. The results showed that the salary indicator showed the respondents' assessment interpretation $49 \%$ agreed and $40 \%$ was sufficient; The position indicator shows the respondent's interpretation of $56 \%$ agree and $30 \%$ is sufficient; the job promotion indicator shows the interpretation of the respondents' assessment. 36\% stated that the category was sufficient and $26 \%$ said the category did not agree; the supervision indicator shows the respondent's assessment interpretation. 57\% agreed and $41 \%$ sufficient. So it can be concluded that overall employees show satisfaction at work.

Copyright (C) Universitas Pendidikan Ganesha. All rights reserved.

\section{Introduction}

Companies need people as resources in carrying out their various activities. Various attention and guidance to human resources is one of the factors that must be continuously improved so that the effectiveness and efficiency of the company can be achieved (Hasibuan, 2003; V. Rivai \& Sagala, 2011). In line with this, humans always play an active role in every activity. This is because humans are planners, actors, and determinants of the realization of the goals of a company (Darmawansyah, 2013; Zurnali, 2010). The achievement of company goals would not have been possible without the active role of employees, despite having sophisticated equipment (Hidayat \& Firdaus, 2014; Sulianti, 2009).

Efforts made in companies are focused on fulfilling human needs, in other words, to be able to live a decent human life based on their human nature, humans have needs that must be met (Mangkunegara, 2015). The ability to meet those needs is an important requirement in placing them in a position following human dignity (Bangun, 2012; Zurnali, 2010).

A person's attitude arises from the existence of wants, needs, and goals. Stimulation can arise from oneself (internal) and outside (external) (Kusuma \& Ardana, 2014; Sarjana, 2012). Stimulation, both material and non-material, will create motivation that encourages people to work (effort) to meet the needs of their work. The whole process of motivation for subordinates aims to make them want to work sincerely to achieve organizational goals effectively and efficiently (Brahmasari \& Suprayetno, 2008; Dhermawan et al., 2012). If subordinates want to work sincerely, what is the goal of the company will be successful and of course, there are factors of job satisfaction and increased employee performance which have an impact on improving organizational performance (Rahmawati et al., 2018). Work is a bridge between employees and organizations, where employees expect rewards from the work completed, while organizations expect work results from employees (Sulianti, 2009). In line with this, there is a need for human resource management to manage good relations between employees and the company.

Human resource management is the selection, development, maintenance, and use of human resources to achieve both individual and organizational goals (Mangkunegara, 2015; Widodo, 2015). No matter how sophisticated the technology is, without human resources capable of handling it, the 
technology is meaningless. This proves that the achievement of industrial goals, especially the hotel industry, is very dependent on the employees who move them (Pramono, 2016). Each employee individually has different job satisfaction.

Job satisfaction is a general attitude towards one's job as the difference between the amount of reward received by workers and the amount of reward that is believed to be received (Sulianti, 2009). Job satisfaction indicators are divided into 5 dimensions, namely: position in the job itself, promotion, supervision, co-workers, and salary (Hadi, 2007; Khair, 2019).

Based on preliminary observations related to job satisfaction, $61.4 \%$ of employees complained that the salary they received was often late, sometimes in one month the salary they received was only partially paid and partially received several weeks later from payday. $54.2 \%$ of employees said that at Premier Basko it was difficult to have a career due to lack of employee training, for example, the Food and Beverage Service employees and sales marketing administration employees who had worked for a long time but did not get a career opportunity.

Employee job satisfaction is important to pay attention to because it will have a direct impact on the results of employee performance itself (Andini, 2006; Khair, 2019). The creation of employee satisfaction at work will be an advantage for the company. If a company has received good work results from employees, the company automatically gets added value so that the visiting guests are also satisfied and carry out the repurchase process (Arifin, 2012; Nabawi, 2020).

Research on employee job satisfaction has been developed before. Research conducted by (H. A. Rivai, 2001; Sarjana, 2012) shows that employee job satisfaction at the company is influenced by salary and supervision carried out by superiors. In line with this, research conducted by (Wolo et al., 2017) shows that job satisfaction has a significant influence in improving the quality of employee work. Therefore, several factors that can affect job satisfaction, such as salary, position in the job, work motivation, and appreciation from the leadership must be considered carefully by the company.

This study aims to analyze the factors that affect employee job satisfaction at the Premier Basko Padang Hotel. The factors analyzed in this study include salary, position, promotion, and supervision.

\section{Method}

This research is quantitative research with a survey method. The population in this study were all employees at Premier Basko Hotel by Lariz Padang. The sample used is a saturated sample, which is a sampling technique when all members of the population are sampled. The details of the sample in this study are presented in Table 1.

Table 1. Research sample

\begin{tabular}{ccc}
\hline No & Department & number of employees \\
\hline 1 & Food \& Beverage Service & 12 \\
2 & Food \& Beverage Product & 14 \\
3 & Front Office & 10 \\
4 & Housekeeping & 16 \\
5 & Marketing & 4 \\
6 & HRD & 2 \\
7 & Accounting & 4 \\
8 & Engineering & 8 \\
\hline
\end{tabular}

The data used in this study are primary data and secondary data. Primary data in question is data that is collected directly by the researcher by distributing questionnaires to the research sample. Secondary data obtained indirectly from the object of research by utilizing existing data from HRD at Premier Basko Hotel Padang. The data collection methods used were questionnaires and documentation. The research instrument used was a questionnaire arranged in a Likert scale. The Likert scale is a measurement scale used to describe the phenomenon of attitudes, opinions, and perceptions of a person or group about social events. Data analysis in this study used a pattern of editing, tabulating, analyzing, interpreting, and concluding 


\section{Results and Discussions}

\section{Results}

Descriptive Analysis

The data of this study were obtained from the results of filling out the instruments in the form of statements to employees who work at Premier Basko Hotel by Lariz Padang which consisted of 30 items. The results of the descriptive analysis of the results of filling out the instruments are presented in Table 2.

Table 2. Results of Descriptive Analysis of Job Satisfaction at Premier Basko Hotel by Lariz Padang

\begin{tabular}{cc}
\hline Variable & Score \\
\hline $\mathrm{N}$ & 70 \\
Mean & 102.34 \\
Median & 103 \\
Std. Deviation & 100 \\
Range & 8.60 \\
Minimum & 41 \\
Maximum & 80 \\
Sum & 121 \\
\hline
\end{tabular}

Based on Table 2, it can be seen that the data regarding employee job satisfaction taken through a questionnaire totaling 30 items of statements given to 70 respondents has a mean of 102.34; median103; mode equal to 100; and the standard deviation is 8.60. The data is an accumulation of several indicators, namely salary, promotion, and supervision.

\section{Salary}

The description of the respondent's assessment of the salary indicator at Premier Basko Hotel by Lariz Padang is presented in Figure 1.

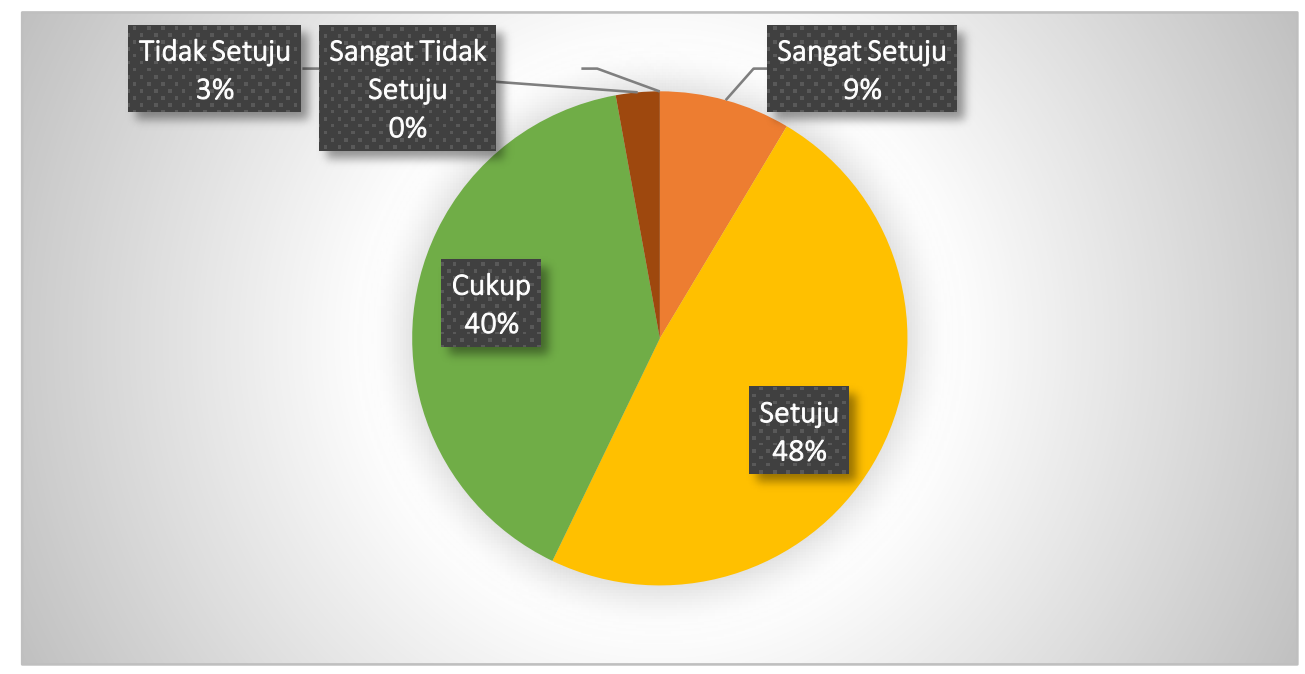

Figure 1. Employee Satisfaction with Salary

Based on the data presented in Figure 1, 9\% of respondents strongly agree, $49 \%$ agree, $40 \%$ are sufficient, and 3\% disagree.

\section{Position}

The description of the respondent's assessment of the position indicator at Premier Basko Hotel by Lariz Padang is presented in Figure 2. 


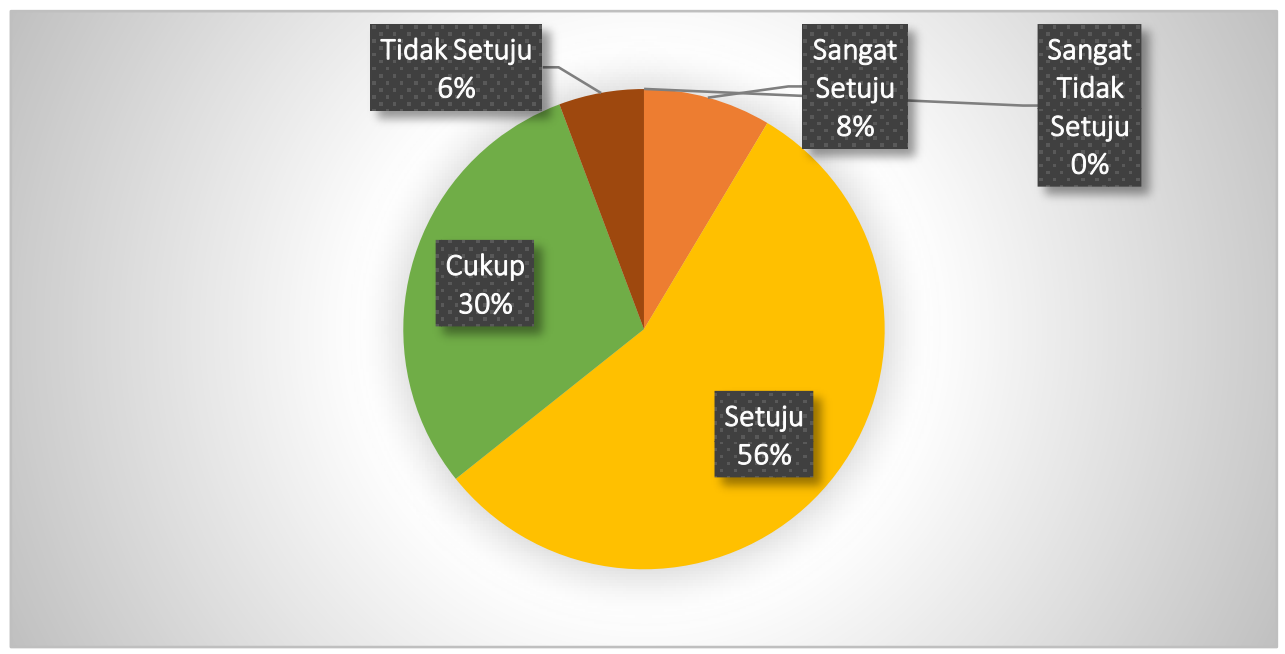

Figure 2. Employee Satisfaction with Position

Based on the data presented in Figure 2, 8\% of respondents strongly agree, $56 \%$ agree, $30 \%$ are sufficient, and $6 \%$ disagree.

\section{Promotion}

The description of the respondent's assessment of the promotion indicator at Premier Basko Hotel by Lariz Padang is presented in Figure 3.

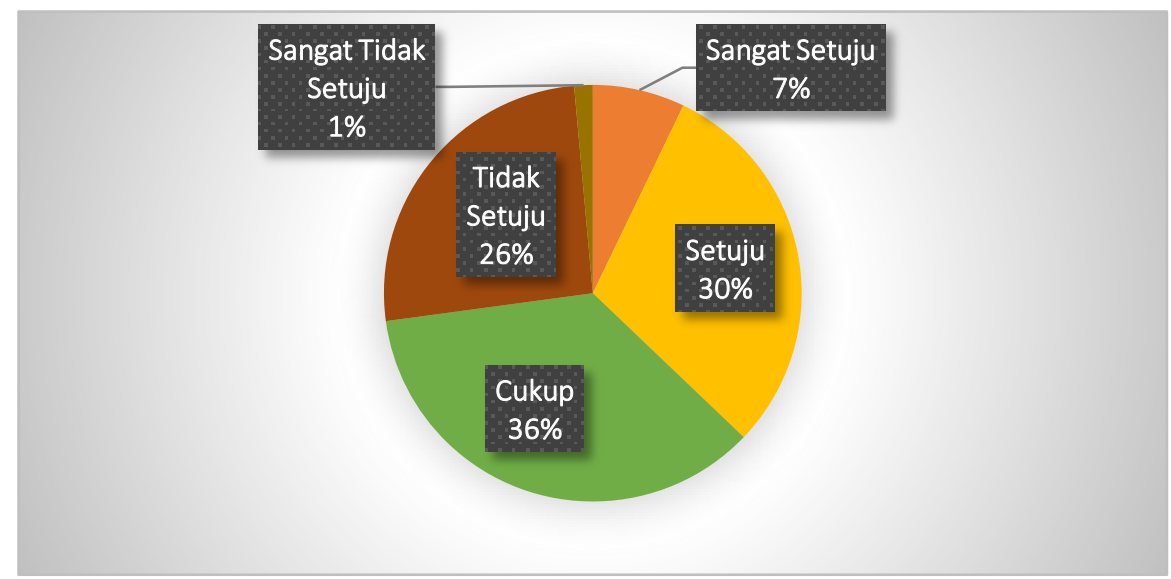

Figure 3. Employee Satisfaction Against Job Promotion

Based on the data presented in Figure 3, 7\% of respondents strongly agree, $30 \%$ agree, $36 \%$ are sufficient, $26 \%$ disagree and $1 \%$ strongly disagree.

\section{Supervision}

The description of the respondent's assessment of the supervision indicator at Premier Basko Hotel by Lariz Padang is presented in Figure 4. 


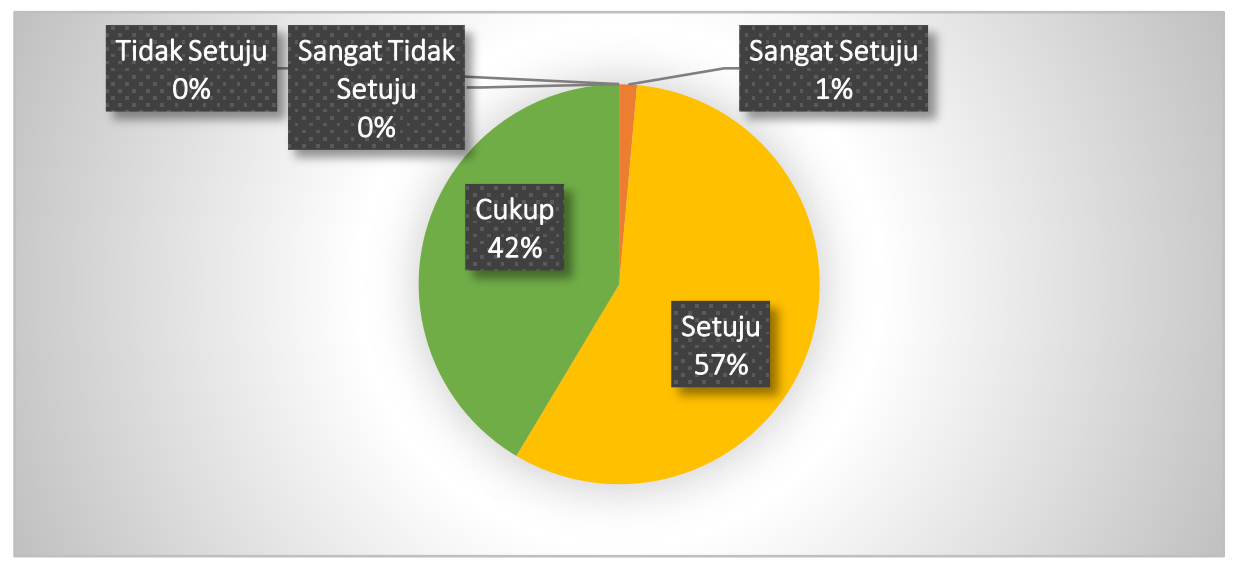

Figure 4. Employee Satisfaction with Supervision

Based on the data presented in Figure 4, 1\% of respondents strongly agree, 57\% agree, and $42 \%$ are sufficient.

\section{Discussion}

This study has found a description of employee job satisfaction at the Premier Basko Padang Hotel. Based on the above data analysis, the interpretation of job satisfaction is described by the indicator. However, in general, it can be stated that the job satisfaction of employees at Hotel Premier Basko Padang shows that the interpretation of the percentage of the assessment is predominantly classified as agreeing is $51 \%$ of the 70 respondents.

Furthermore, we can see that the Premier Basko Padang Hotel has not provided maximum job satisfaction following the expectations of the working employees. Even though it has been categorized as agreeing, the hotel must increase job satisfaction so that the assessment of employees who work is categorized as strongly agree. Job satisfaction is a feeling that supports or does not support employees who are related to their work or their condition (Darmawansyah, 2013; Kusuma \& Ardana, 2014). From the existing theory, it can be seen that the job satisfaction provided by the Premier Basko Padang Hotel has not maximally fulfilled the needs and desires of employees following employee expectations in terms of 4 job satisfaction indicators.

\section{Salary}

Employee job satisfaction at the Premier Basko Padang Hotel in terms of the dominant salary indicator is categorized as agreeing with the interpretation of the percentage of the assessment of $49 \%$ of 70 respondents. In this case, we can see that the Premier Basko Hotel has not provided maximum satisfaction following the expectations of employees who work in terms of salary indicators. It can be seen that the questionnaire statement assessed by the employee needs to be improved, the salary received is not on time which does not match the date of receipt of monthly salary, the salary earned is not following the position, the salary increase is not following the increase in work performance.

Salary is the payment or delivery of services made by employees who have a managerial level, while wages are generally payments for the delivery of services made by implementing employees (laborers). Generally, salaries are paid regularly per month, while wages are paid based on working days, working hours, or the number of units of product produced (Andini, 2006; H. A. Rivai, 2001).

From the existing theory, it is clear that the job satisfaction provided by the Premier Basko Hotel in terms of the salary indicators has met the needs and desires of employees but has not achieved maximum results according to the expectations of employees who work at Premier Basko Hotel Padang.

\section{Position}

Employee job satisfaction at the Premier Basko Padang Hotel in terms of the job indicator itself is dominant categorized as agree with the interpretation of the percentage of the assessment is $56 \%$ of 70 respondents. In this case, we can see that the Premier Basko Padang Hotel has not provided maximum satisfaction following the expectations of employees who work in terms of the job indicators themselves. It can be seen that the questionnaire statement assessed by employees that need to be improved is employees who are not responsible for their work. 
Work is a group of positions (positions) that have similar obligations or main duties. In job analysis activities, one job can be occupied by one person, or several people who are scattered in various places (Cahyono \& Ghozali, 2002; Nugraha et al., 2016). From the existing theory, it is clear that the job satisfaction provided by the Premier Basko Hotel in terms of the job indicators itself has met the needs and desires of employees but has not achieved maximum results following the expectations of employees who work at Premier Basko Hotel Padang.

\section{Promotion}

Employee job satisfaction at the Premier Basko Padang Hotel in terms of indicators of dominant job promotion is categorized as sufficient with the interpretation of the percentage of the assessment is $36 \%$ of 70 respondents. In this case, we can see that the Premier Basko Padang Hotel has not provided maximum satisfaction following the expectations of employees who work in terms of promotion indicators. It can be seen that the questionnaire statement assessed by employees needs to be improved, namely that every employee does not get the same opportunity for promotion, promotion is not based on the work performance of each employee, and employee promotions are not transparent.

Promotion is a change in position or employment from a lower level to a higher level, usually followed by an increase in one's responsibilities, rights, and social status (Nugraha et al., 2016). From the existing theory, it is clear that the job satisfaction provided by the Premier Basko Hotel in terms of indicators of promotion has met the needs and desires of employees but has not achieved maximum results following the expectations of employees who work at the Premier Basko Hotel Padang.

\section{Supervision}

Employee job satisfaction at the Premier Basko Padang Hotel in terms of dominant supervision indicators is categorized as agreeing with the interpretation of the percentage of the assessment of $57 \%$ of 70 respondents. In this case, we can see that the Premier Basko Padang Hotel has not provided maximum satisfaction following the expectations of employees who work in terms of supervision indicators. It can be seen that the questionnaire statement assessed by employees needs to be improved, the supervisor assigns tasks that are not following the employees' abilities, the schedule given by the supervisor is burdensome for the employees, the supervisor does not provide an even workload to all employees.

Supervisors are managers who are responsible to a higher-level manager and whose main task is to lead workers at the operational level (Hadi, 2007; Sarjana, 2012). From the existing theory, it is clear that the job satisfaction provided by the Premier Basko Hotel in terms of the supervision indicators has met the needs and desires of employees but has not achieved maximum results following the expectations of employees who work at the Premier Basko Hotel Padang.

\section{Conclusion}

Job satisfaction is a general attitude towards one's job as the difference between the amount of reward received by workers and the amount of reward that is believed to be received. Overall, employees at the Premier Basko Padang Hotel show their satisfaction at work. This can be seen from four indicators, namely salary, position, promotion, and supervision.

\section{References}

Andini, R. (2006). Analisis Pengaruh Kepuasan Gaji, Kepuasan Kerja, Komitmen Organisasional Terhadap Turnover Intention (Studi Kasus Pada Rumah Sakit Roemani Muhammadiyah Semarang) [Universitas Diponegoro]. http://eprints.undip.ac.id/15830/

Arifin, N. (2012). Analisis Kualitas Kehidupan Kerja, Kinerja, dan Kepuasan Kerja Pada CV Duta Senenan Jepara. Jurnal Economia, 8(1), 11-21. https://doi.org/10.21831/economia.v8i1.797

Bangun, W. (2012). Manajemen Sumber Daya Manusia. Erlangga.

Brahmasari, I. A., \& Suprayetno, A. (2008). Pengaruh Motivasi Kerja, Kepemimpinan dan Budaya Organisasi Terhadap Kepuasan Kerja Karyawan Serta Dampaknya Pada Kinerja Perusahaan (Studi Kasus Pada PT. Pei Hai International Wiratama Indonesia). Jurnal Manajemen Dan Kewirausahaan, 10(2), 124-135. https://doi.org/10.9744/jmk.10.2.pp.\%20124-135

Cahyono, D., \& Ghozali, I. (2002). Pengaruh Jabatan, Budaya Organisasional dan Konflik Peran terhadap Hubungan Kepuasan Kerja dengan Komitmen Organisasi: Studi Empiris di Kantor Akuntan Publik. The Indonesian Journal of Accounting Research, 5(3). https://doi.org/10.33312/ijar.86

Darmawansyah. (2013). Penerapan Prinsip- prinsip Good Corporate Governance Terhadap Kepuasan 
Kerja dan Kinerja Karyawan. Jurnal AKK Indonesia, 2(2).

Dhermawan, A. A. N. B., Sudibya, I. G. A., \& Utama, I. W. M. (2012). Pengaruh motivasi, lingkungan kerja, kompetensi, dan kompensasi terhadap kepuasan kerja dan kinerja pegawai di lingkungan kantor Dinas Pekerjaan Umum Provinsi Bali. Matrik: Jurnal Manajemen, Strategi Bisnis Dan Kewirausahaan, 6(2), 173-184. https://ocs.unud.ac.id/index.php/jmbk/article/view/2203

Hadi, S. (2007). Pengaruh Tindakan Supervisi Terhadap Kepuasan Kerja Akuntan Pemula. Jurnal Akuntansi Dan Auditing Indonesia, 11(2). https://journal.uii.ac.id/JAAI/article/view/220

Hasibuan, M. S. . (2003). Manajemen Sumber Daya Manusia. Bumi Aksara.

Hidayat, D. R., \& Firdaus, M. R. (2014). Analisis Pengaruh Kualitas Layanan, Harga, Kepercayaan, Citra Perusahaan, Dan Kepuasan Pelanggan Terhadap Loyalitas Pelanggan (Studi Pada Pelanggan Telkom Speedy Di Palangka Raya). JWM: Jurnal Wawasan Manajemen, 2(3), 237-250. https://doi.org/10.20527/jwm.v2i3.16

Khair, H. (2019). Pengaruh Kepemimpinan Dan Kompensasi Terhadap Kepuasan Kerja Melalui Motivasi Kerja. Maneggio: Jurnal Ilmiah Magister Manajemen, 2(1), 69-88. https://doi.org/10.30596/maneggio.v2i1.3404

Kusuma, I. P. S. W., \& Ardana, K. (2014). Pengaruh Penempatan dan Kompensasi Terhadap Kepuasan Kerja dan Kinerja Karyawan. E-Jurnal Manajemen, https://ocs.unud.ac.id/index.php/Manajemen/article/view/8286

Mangkunegara, A. A. . (2015). Manajemen Sumber Daya Manusia Perusahaan (12th ed.). Pt Remaja Rosdakarya.

Nabawi, R. (2020). Pengaruh Lingkungan Kerja, Kepuasan Kerja dan Beban Kerja Terhadap Kinerja Pegawai. Maneggio: Jurnal Ilmiah Magister Manajemen, 2(2), 170-183. https://doi.org/10.30596/maneggio.v2i2.3667

Nugraha, I., Bayu, M., \& Surya, I. B. K. (2016). Pengaruh Kompensasi, Lingkungan Kerja dan Promosi Jabatan Terhadap Kepuasan Kerja. E-Jurnal Manajemen Universitas Udayana, 5(1). https://www.neliti.com/publications/255266/pengaruh-kompensasi-lingkungan-kerja-danpromosi-jabatan-terhadap-kepuasan-kerja

Pramono, J. (2016). The Process of Environmental Management at Star Rated Hotel in Bali. In Tourism \& Sustainable Regional Development In Indonesia. (pp. 20-32). Unpad Press.

Rahmawati, E., Nujanah, S., \& Retnaningsih, W. (2018). Pengaruh Self Leadership, Kecerdasan Sosial, Employee Ability Terhadap Komitmen Organisasional Dan Kinerja Karyawan Dinas Pengendalian Penduduk, Pemberdayaan Perempuan Dan Perlindungan Anak Kota Surabaya. Jurnal Ilmu Ekonomi Dan Manajemen, 5(2). http://jurnal.untagsby.ac.id/index.php/jmm17/article/view/1945

Rivai, H. A. (2001). Pengaruh Kepuasan Gaji, Kepuasan Kerja, Dan Komitmen Organisasi Terhadap Intensi Keluar: Pengujian Empiris Model Turnover. Jurnal Bisnis Dan Akuntansi, 3(1), 335-352. https://doi.org/10.34208/jba.v3i1.510

Rivai, V., \& Sagala, E. J. (2011). Manajemen Sumber Daya Manusia Untuk Perusahaan Dari Teori ke Praktik. Rajawali Pers.

Sarjana, S. (2012). Pengaruh Supervisi dan Iklim Organisasi Terhadap Kepuasan Kerja. Jurnal Kependidikan: Penelitian Inovasi Pembelajaran, 42(2). https://doi.org/10.21831/jk.v42i2.2243

Sulianti, D. (2009). Pengaruh Komitmen Organisasi, dan Kepuasan Kerja Terhadap Kinerja Karyawan PT. Perkebunan Nusantara III di Sumatra Barat. Jurnal Manajemen Dan Kewirausahaan, 11(1), 31-37. https://doi.org/10.9744/jmk.11.1.pp.\%2031-37

Widodo, S. (2015). Manajemen Pengembangan Sumber Daya Manusia. Pustaka Pelajar.

Wolo, P. D., Trisnawati, R., \& Wiyadi, W. (2017). Faktor Faktor Yang Mempengaruhi Kepuasan Kerja Perawat Pada RSUD TNI AU Yogyakarta. Jurnal Manajemen Dayasaing, 17(2), 78-87. http://journals.ums.ac.id/index.php/dayasaing/article/viewFile/3777/2446.

Zurnali, C. (2010). Kwoladge Worker: Kerangka Riset Manajemen Sumber Daya Manusia Masa Depan. Unpad Press. 